\title{
Effects of dietary vitamin A intake on acrosin- and plasminogen-activator activity of ram spermatozoa
}

\author{
I A Zervos, M P Tsantarliotou ${ }^{1}$, G Vatzias ${ }^{2}$, P Goulas $^{3}$, N A Kokolis ${ }^{1}$ and I A Taitzoglou ${ }^{1}$ \\ Laboratory of Physiology, School of Veterinary Medicine, University of Thessaly, Karditsa, Greece, ${ }^{1}$ Laboratory of \\ Physiology, School of Veterinary Medicine, Aristotle University of Thessaloniki, University Campus, 54124 \\ Thessaloniki, Greece, ${ }^{2}$ Laboratory of Physiology, Department of Animal Production, Technological Educational \\ Institute of Epirus, Arta, Greece and ${ }^{3}$ Department of Animal Production, Technological Educational Institute, \\ Larissa, Greece \\ Correspondence should be addressed to I A Taitzoglou; Email: jotai@vet.auth.gr
}

\begin{abstract}
Acrosin and plasminogen activators are proteolytic enzymes of ram spermatozoa that play an essential role in the induction of the acrosome reaction, as well as the binding of spermatozoa to the oocyte and their penetration through the layers that surround the oocyte. Since vitamin A can alter gene expression in various tissues, testis included, this study was undertaken to evaluate the possible effect of vitamin A intake on acrosin- and plasminogen-activator activity. During a 20-week experiment, 15 rams of the Greek breed Karagouniki, divided to three groups, received different amounts of vitamin A per os in retinyl acetate capsules (group A, controls, $12500 \mathrm{iu} / \mathrm{animal}$ per day; group B, $50000 \mathrm{iu} / \mathrm{animal}$ per day; group C, $0 \mathrm{iu} / \mathrm{animal}$ per day up to the 13th week, then 150000 iu/animal per day until the end of the experiment). Acrosin- and plasminogen-activator activity were determined by spectrophotometric methods. Vitamin A was determined in blood plasma by HPLC. No statistical differences were detected regarding the body weight of the rams or the qualitative and quantitative parameters of their ejaculate throughout the whole experiment. No statistically significant alterations of enzyme activity were detected in group B. In group $C$, both enzyme activities started declining in week 9. Compared with controls, maximum reduction for acrosin was $49 \%$ on week 11 and for plasminogen activators $51 \%$ in week 14 . Activities returned to normal rates after vitamin $A$ resupplementation. To date, the main result of vitamin A deficiency was known to be arrest of spermatogenesis and testicular degeneration. A new role for vitamin A may be suggested, since it can influence factors related to male reproductive ability before spermatogenesis is affected.

Reproduction (2005) 129 707-715
\end{abstract}

\section{Introduction}

There is accumulated evidence that acrosomal enzymes play an essential role in the induction of the acrosome reaction, and the binding of sperm to and their penetration through the layers that surround the oocyte (Yanagimachi 1994). The most widely studied acrosomal enzyme is the endoproteinase acrosin (EC 3.4.21.10). The presence of this sperm acrosomal serine proteinase in the acrosome of ram spermatozoa was proved 30 years ago (Zaneveld et al. 1973, Srivastava et al. 1974). Today we know that acrosin is involved in the acrosome reaction (Tesařik et al. 1988, De Jonge et al. 1989), the recognition and binding of spermatozoa to the zona pellucida (Saling 1981, Jones 1991), the penetration of the zona pellucida by spermatozoa (Kennedy et al. 1983, Schill 1991), the fusion of the gamete membranes (Tesařik 1995) and development of the block to polyspermy by zona hardening (Smith et al. 2000).

There are at least two types of plasminogen activator (PA) in mammals: the tissue-type PA (t-PA) and the urokinase-type PA (u-PA); both convert the abundant extracellular zymogen plasminogen into plasmin, which is the active proteinase that stimulates fibrinolysis and proteolysis. PAs, as well as PA inhibitors (PAIs) and plasmin inhibitors, have been found in ejaculated spermatozoa from various species, sheep included (Smokovitis et al. 1987). The PAs and their inhibitors are localized to the outer acrosomal membrane and plasma membrane of human and boar spermatozoa (Smokovitis et al. 1992). It has been proved that, during the acrosome reaction, PAs are released in human, boar, bull and ram spermatozoa (Taitzoglou et al. 1996), and that plasmin induces the acrosome reaction (Taitzoglou et al. 2003) and influences various motility 
parameters (Taitzoglou et al. 2004) in bull spermatozoa. A number of studies show a positive correlation between PA activity (PAA) of human spermatozoa and their fertilizing ability (Lison et al. 1993, Liu et al. 1996, Huang et al. 1997).

Vitamin A is required for several critical life processes, including reproduction, metabolism, differentiation, hematopoiesis, bone development, and pattern formation during embryogenesis (Sporn et al. 1994). In the testis, vitamin $A$ is required for the normal production of spermatozoa (Mason 1933). In the seminiferous epithelium of vitamin A-deficient mice, a depletion of germ cells occurs. Only Sertoli cells, type A spermatogonia, and occasionally a few degenerating spermatids are present (van Pelt \& de Rooij 1990). Resupplementation of retinol (Morales \& Griswold 1987) or retinoic acid (van Pelt \& de Rooij 1991) results in the re-initiating of spermatogenesis in a synchronized manner. The mechanism by which retinoids elicit their effects ultimately resides in their ability to regulate gene expression at specific target sites (Mangelsdorf 1994). Several types of retinoid receptor have been identified; among them, the types retinoic acid receptor $\alpha_{1}$ $\left(\operatorname{RAR} \alpha_{1}\right), \operatorname{RAR} \gamma($ Kim \& Wang 1993) and retinoid X receptor $\gamma(R X R \gamma$; Huang et al. 1994) have been identified in the testis. These receptors are active during the whole of spermatogenesis and until the phase of elongating spermatids in spermiogenesis (Dufour \& Kim 1999).

It is known that retinoids can affect various parameters of the fibrinolytic system. Indeed, experiments in vitro showed that retinoids increase t-PA synthesis by human endothelial cells (Kooistra et al. 1991), while they enhance t-PA levels in rat tissues in vivo (van Bennecum et al. 1993). Furthermore, retinoids, when supplemented per os, affect various parameters of the human fibrinolytic system (Declerck et al. 1993). On the contrary, to our knowledge the possible effect of vitamin A on acrosin activity has not been investigated to date. Therefore, the present study was undertaken to investigate the effect of excessive vitamin A intake or vitamin A deprivation on the activity of acrosin and PAs of ram spermatozoa, and their possible correlation.

\section{Materials and Methods}

The study was carried out between 16 January and 29 May 2002. 15 rams of the Greek breed Karagouniki were used. At the onset of the study all animals were 23 months old and had approximately the same body weight $(78 \pm 6 \mathrm{~kg})$. The rams were weighed weekly throughout the experiment. During the experiment all rams were kept under natural daylight conditions; they were in good health and were not treated pharmaceutically. Starting on 1 December 2001, and until the end of the experiment, they were kept on a vitamin A-deficient diet consisting of barley $(62.07 \%$, w/w), wheat bran $(19.99 \%$, w/w), soya $\left(12.80 \%\right.$, w/w), limestone $(3.76 \%, w / w), \mathrm{Ca}_{3}\left(\mathrm{PO}_{4}\right)_{2}(0.1 \%$, $\mathrm{w} / \mathrm{w}), \mathrm{NaCl}(0.7 \%, \mathrm{w} / \mathrm{w}), \mathrm{NH}_{4} \mathrm{Cl}(0.40 \%, \mathrm{w} / \mathrm{w})$, sufrum
$(0.08 \%$, w/w), vitamin and mineral supplement $(0.1 \%$, w/w), and barley straw ad libitum. On 16 January 2002 (week 1 of the experiment) the rams were divided into three groups with five animals each, and received different amounts of vitamin A per os as retinyl acetate (ROVIMIX ${ }^{\circledR}$ A 500; kindly offered by Roche Vitamins, Hellas, Greece), in capsules produced in our laboratory (group A, controls, $12500 \mathrm{iu} / \mathrm{animal}$ per day; group B, $50000 \mathrm{iu} / \mathrm{animal}$ per day; group C, 0 iu/animal per day up to 13th week, then $150000 \mathrm{iu} / a n i m a l$ per day until the end of the experiment). Except when mentioned otherwise, all chemicals were provided by Sigma-Aldrich (Steinheim, Germany). The plasminogen used was isolated from ovine blood plasma by affinity chromatography on lysine-Sepharose 4B as described by Deutsch and Mertz (1970).

Blood samples and semen samples were collected weekly. The ejaculated semen was collected using a small ruminant artificial vagina. Immediately after collection, sperm motility was evaluated subjectively by preparing a wet mount of the spermatozoa and estimating the percentage of motile spermatozoa in four fields. Additionally, sperm concentration was determined using a Neubauer hemocytometer. Acrosomal status, viability and percentage of abnormal forms were evaluated using the staining procedure eosin/nigrosin (Thompson \& Cummins 1985). Spermatozoa were classified as (1) dead with intact acrosome, (2) dead with detached acrosome, (3) live with intact acrosome and (4) live with detached acrosome. Slides were examined with a bright-field microscope. For classification, microscope fields were selected at random and all spermatozoa in each field were evaluated until 200 spermatozoa per slide were examined.

\section{Acrosin assay}

Preparation of solutions was as follows. Ficoll: 11\% (w/v) Ficoll was diluted in $0.12 \mathrm{M} \mathrm{NaCl} / 0.025 \mathrm{M}$ Hepes buffer, $\mathrm{pH}$ 7.4. Benzamidine solution was made by dissolving a peptidase inhibitor in water to the concentration of $0.5 \mathrm{M}$. $\mathrm{N}$ - $\alpha$-benzoyl-DL-arginine para-nitroanilide-HCL (BAPNA) extender was made with $0.01 \%(\mathrm{v} / \mathrm{v})$ Triton $\mathrm{X}-100$ in $0.055 \mathrm{M}$ Hepes/0.055 $\mathrm{M} \mathrm{NaCl}$ at $\mathrm{pH}$ 8.0. BAPNA was diluted in DMSO to a concentration of $23 \mathrm{mM}$. Immediately before use it was further diluted nine times with BAPNA extender.

Acrosin activity was determined in ram spermatozoa by spectrophotometry (Kennedy et al. 1989). In brief, $5 \mu \mathrm{l}$ of each ejaculate were placed in $1000 \mu \mathrm{l} \mathrm{NaCl} / \mathrm{Hepes}, \mathrm{pH}$ 7.4 , vortexed, and a volume containing $2 \times 10^{6}$ spermatozoa was washed with Ficoll solution. After rediluting the washed spermatozoa, $0.5 \times 10^{6}$ sperm cells were diluted in $\mathrm{NaCl} /$ Hepes to a final volume of $100 \mu \mathrm{l}$. $100 \mu \mathrm{l}$ benzamidine solution were added to control tubes and $1000 \mu \mathrm{l}$ BAPNA solution were added to all tubes after vortexing. After $90 \mathrm{~min}$ incubation at $37^{\circ} \mathrm{C}, 100 \mu \mathrm{l}$ benzamidine solution were added to test tubes and all tubes were centrifuged at $1000 \mathrm{~g}$ for $15 \mathrm{~min}$. Supernatants were collected 
and the absorbance was read at $410 \mathrm{~nm}$. The difference between control and test tubes was adopted as net absorbance. Acrosin activity was expressed as $\mu$ iu $10^{-6}$ spermatozoa, as calculated by the formula suggested by Kennedy et al. (1989).

\section{PAA assay}

The following solutions were used: $0.73 \mathrm{mM}$ chromogenic substrate solution (S-2251; Chromogenix Milano, Italy); $50 \%(\mathrm{v} / \mathrm{v})$ acetic acid; and extraction solution prepared by mixing 4 vol $0.1 \mathrm{M}$ Tris/ $\mathrm{HCl}$ buffer and $1 \mathrm{vol} 0.5 \mathrm{M}$ potassium thiocyanate.

Spermatozoa were centrifuged twice with natural saline in order to wash away the seminal plasma. A sample volume containing $1 \times 10^{8}$ spermatozoa was vortexed in $1000 \mu \mathrm{l}$ extraction solution and centrifuged at $3000 \mathrm{~g}$ for $10 \mathrm{~min}$, and supernatants were collected and stored at $-70^{\circ} \mathrm{C}$ until assayed.

PAA was determined by spectrophotometry as described in detail by Smokovitis et al. (1987). A total volume of $500 \mu \mathrm{l}$ mixture consisting of $200 \mu \mathrm{l}$ substrate solution, $100 \mu \mathrm{l}$ plasminogen solution (final concentration, 0.5 casein units $\mathrm{ml}^{-1}$ ), $100 \mu \mathrm{l}$ Tris/ $\mathrm{HCl}$ buffer and $100 \mu \mathrm{l}$ of the acrosomal extract was incubated for $30 \mathrm{~min}$ at $37^{\circ} \mathrm{C}$. The reaction was terminated by adding $1000 \mu \mathrm{l} 50 \%(\mathrm{v} / \mathrm{v})$ acetic acid. The absorbance was read at $405 \mathrm{~nm}$. The difference between control and test tubes was adopted as net absorbance. PAA was expressed as iu t-PA $10^{-8}$ spermatozoa, referring to a standard curve designed using 1-50 iu t-PA (Biopool AB, Umeå Sweden).

\section{Vitamin A determination in blood plasma}

Three metabolites of vitamin A (retinoic acid, retinol, and retinyl palmitate) were determined in ram blood plasma using a HPLC method that was specially designed for this project (Moulas et al. 2003). Figure 1 shows typical chromatograms of a standard solution (Fig. 1a) and a ram blood plasma sample (Fig. 1b). In brief, samples of $200 \mu \mathrm{l}$ were extracted with 2-propanol-dichloromethane, the extracts were centrifuged, and supernatants were collected, evaporated, reconstituted in mobile phase, and analyzed on a $C_{8}$ column using two consecutive isocratic elutions with methanol tetrahydrofuran-acetate buffer. Detection was performed at 350 and $325 \mathrm{~nm}$ using wavelength changes during the run. The method exhibits analytical characteristics well within the acceptable limits. Overall recoveries were $73.7 \%$ for retinoic acid, $90.2 \%$ for retinol, and $87.7 \%$ for retinyl palmitate. Precision values, expressed as the percentage relative standard deviation, were in the range of $1.16-6.18 \%$, while limits of detection were $0.3 \mathrm{ng} \mathrm{ml}^{-1}$ for retinoic acid, $6.0 \mathrm{ng} \mathrm{ml}^{-1}$ for retinol, and $10.0 \mathrm{ng} \mathrm{ml}^{-1}$ for retinyl palmitate.

\section{Statistical analysis}

For the statistical analysis, the SPSS (version 10.0) was used. The level of significance was $P<0.05$. When
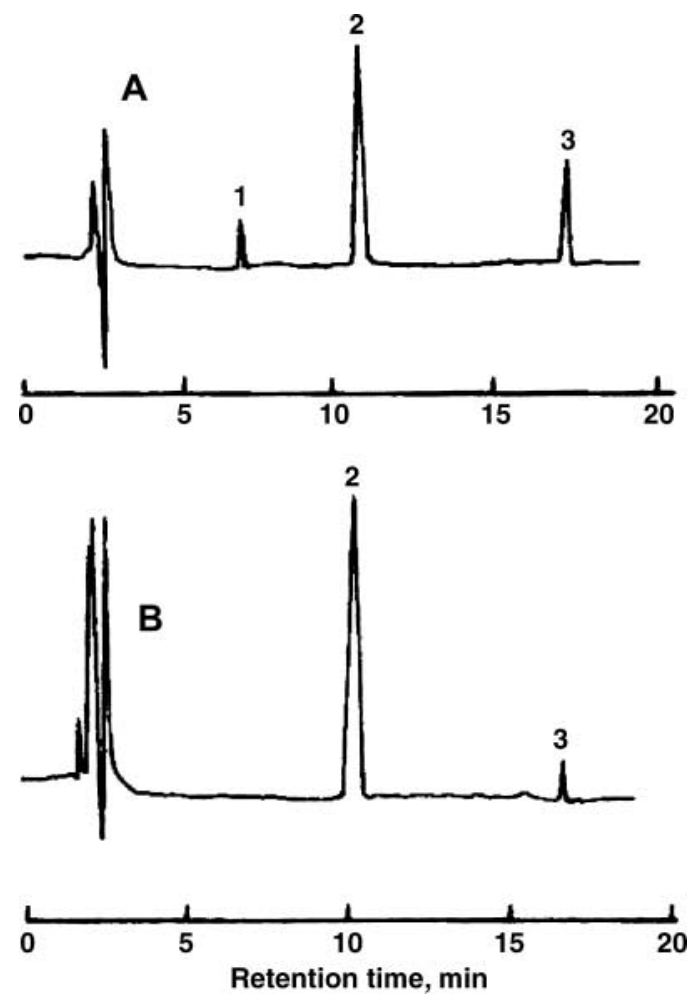

Figure 1 Typical chromatogram of a standard solution (a) and a ram blood plasma sample (b) containing $198.1 \mathrm{ng} \mathrm{ml}^{-1}$ retinol and $16.2 \mathrm{ng} \mathrm{ml}^{-1}$ retinyl palmitate. Peak identification: 1 , retinoic acid; 2, retinol; 3, retinyl palmitate.

distributions and variations permitted the use of parametric hypothesis tests, ANOVA was used to calculate differences among the three groups, followed by the Duncan test, while the calculation of median differences between two independent groups was performed by Student's $t$ test. When parametric hypothesis tests could not be used, the Kruskall-Wallis test was performed in order to calculate differences among the three groups, followed by the Mann-Whitney $U$ test to specify differences between two independent groups. The Pearson correlation coefficient between retinol concentration and acrosin or PAA was calculated with a simple linear-regression equation.

\section{Results}

The body weight of the animals did not change significantly throughout the experiment. The sperm concentrations did not show any statistically significant differences among the three groups, throughout the whole experiment, and neither did the spermatozoal motility or the percentage of morphologically normal forms (Table 1). Sperm viability and acrosomal status of control and treated samples showed no statistical differences.

\section{Acrosin activity}

Acrosin activity in group B showed no statistically significant differences compared with controls. On the contrary, 
Table 1 Mean ( \pm S.D.) values of sperm concentration $\left(10^{6} \mathrm{ml}^{-1}\right)$, mean percentage ( \pm S.D.) of motility, and mean percentage ( \pm S.D.) of normal forms in ram ejaculates. Group A (controls), 12500 iu vitamin A/animal per day; group B: 50000 iu vitamin A/animal per day; group c: 0 iu vitamin A/animal per day until the $13^{\text {th }}$ week, the 15000 iu vitamin A/animal per day until the end of the experiment.

\begin{tabular}{|c|c|c|c|c|c|c|c|c|c|}
\hline \multirow[b]{2}{*}{ Week } & \multicolumn{3}{|c|}{ Group A } & \multicolumn{3}{|c|}{ Group B } & \multicolumn{3}{|c|}{ Group C } \\
\hline & Concentration & Motility & Normal forms & Concentration & Motility & Normal forms & Concentration & Motility & Normal forms \\
\hline 1 & $3984 \pm 48035$ & $74 \pm 5.48$ & $91.2 \pm 5.80$ & $3281 \pm 62581$ & $70 \pm 9.35$ & $91.8 \pm 3.96$ & $3360 \pm 51056$ & $74 \pm 5.48$ & $88 \pm 5.56$ \\
\hline 2 & $3945 \pm 46384$ & $73 \pm 7.58$ & $89.6 \pm 4.33$ & $4781 \pm 89573$ & $72 \pm 6.71$ & $88.2 \pm 4.49$ & $3605 \pm 71223$ & $73 \pm 5.70$ & $91.6 \pm 4.72$ \\
\hline 3 & $3620 \pm 69169$ & $75 \pm 3.54$ & $88 \pm 6.89$ & $4468 \pm 84515$ & $72 \pm 7.58$ & $90.6 \pm 3.97$ & $4637 \pm 75427$ & $75 \pm 3.54$ & $91.6 \pm 4.21$ \\
\hline 4 & $4791 \pm 109812$ & $76 \pm 5.48$ & $91 \pm 4.35$ & $4286 \pm 79666$ & $71 \pm 8.22$ & $88.6 \pm 5.27$ & $3290 \pm 9554$ & $71 \pm 5.48$ & $88 \pm 5.95$ \\
\hline 5 & $3870 \pm 49454$ & $73 \pm 5.70$ & $89.2 \pm 4.08$ & $4470 \pm 81556$ & $70 \pm 6.12$ & $90.2 \pm 3.63$ & $4470 \pm 64121$ & $72 \pm 7.58$ & $88.4 \pm 4.39$ \\
\hline 6 & $4295 \pm 92368$ & $73 \pm 5.70$ & $90.6 \pm 5.27$ & $3052 \pm 82354$ & $71 \pm 7.42$ & $87 \pm 6.041$ & $3480 \pm 53667$ & $75 \pm 0$ & $88.2 \pm 3.96$ \\
\hline 7 & $3270 \pm 75765$ & $76 \pm 2.24$ & $89.6 \pm 4.72$ & $3350 \pm 74891$ & $72 \pm 8.37$ & $89.2 \pm 3.83$ & $4365 \pm 85405$ & $76 \pm 6.52$ & $87 \pm 5.52$ \\
\hline 8 & $4115 \pm 8276$ & $74 \pm 6.52$ & $90.4 \pm 3.84$ & $3050 \pm 61522$ & $74 \pm 5.48$ & $87.8 \pm 3.96$ & $3085 \pm 60733$ & $75 \pm 3.54$ & $88.4 \pm 3.71$ \\
\hline 9 & $2940 \pm 71565$ & $74 \pm 8.22$ & $90 \pm 4.30$ & $2793 \pm 78556$ & $71 \pm 8.22$ & $89.6 \pm 4.50$ & $4066 \pm 98377$ & $71 \pm 5.48$ & $87.8 \pm 3.89$ \\
\hline 10 & $4035 \pm 52064$ & $73 \pm 7.58$ & $89 \pm 3.08$ & $3637 \pm 71603$ & $77 \pm 2.74$ & $90.2 \pm 4.38$ & $4685 \pm 77414$ & $74 \pm 4.18$ & $92.2 \pm 4.43$ \\
\hline 11 & $3700 \pm 67265$ & $72 \pm 9.08$ & $90.4 \pm 6.22$ & $4825 \pm 11255$ & $74 \pm 5.48$ & $88.4 \pm 4.92$ & $4785 \pm 88341$ & $72 \pm 7.58$ & $91 \pm 5.29$ \\
\hline 12 & $3210 \pm 82598$ & $71 \pm 8.22$ & $90.2 \pm 5.31$ & $3240 \pm 74988$ & $73 \pm 5.70$ & $88.6 \pm 3.04$ & $3460 \pm 86751$ & $74 \pm 5.48$ & $92.4 \pm 5.31$ \\
\hline 13 & $4150 \pm 53265$ & $72 \pm 7.58$ & $87 \pm 6.89$ & $4335 \pm 72856$ & $72 \pm 5.70$ & $87.2 \pm 4.96$ & $4900 \pm 68525$ & $75 \pm 6.12$ & $90 \pm 3.74$ \\
\hline 14 & $4130 \pm 52978$ & $72 \pm 5.70$ & $87 \pm 6.32$ & & & & $3690 \pm 55474$ & $74 \pm 2.24$ & $86.6 \pm 4.27$ \\
\hline 15 & $4305 \pm 54314$ & $74 \pm 8.22$ & $88.2 \pm 6.37$ & & & & $4410 \pm 6179$ & $74 \pm 4.18$ & $90.2 \pm 5.01$ \\
\hline 16 & $4875 \pm 55132$ & $72 \pm 5.70$ & $84.6 \pm 5.45$ & & & & $4275 \pm 58422$ & $71 \pm 6.52$ & $86 \pm 4.24$ \\
\hline 17 & $4155 \pm 50602$ & $71 \pm 8.22$ & $92 \pm 3.53$ & & & & $3775 \pm 59672$ & $73 \pm 5.70$ & $90.2 \pm 4.26$ \\
\hline 18 & $4100 \pm 49987$ & $70 \pm 9.35$ & $88 \pm 5.70$ & & & & $3795 \pm 52356$ & $74 \pm 5.48$ & $90.4 \pm 6.02$ \\
\hline 19 & $4010 \pm 6525$ & $70 \pm 7.07$ & $88.6 \pm 5.12$ & & & & $3200 \pm 50608$ & $73 \pm 4.47$ & $91.6 \pm 8.20$ \\
\hline 20 & $4456 \pm 98219$ & $72.5 \pm 6.45$ & $89.2 \pm 5.16$ & & & & $3190 \pm 75984$ & $75 \pm 8.66$ & $89.8 \pm 5.35$ \\
\hline
\end{tabular}

in group $\mathrm{C}$ there was a reduction in acrosin activity, starting in the 10th week and lasting up to the 18th week. In this group, the lowest activity was noticed in the 18th week, when a $54.5 \%$ reduction was observed (Fig. 2).

\section{PAA}

Rams of group B had no significant difference in their spermatozoal PAA, compared with controls. PAA in group $C$ followed a pattern similar to that of acrosin, showing a reduction between weeks 10 and 18 . Nevertheless, the strongest effect of vitamin A deprivation was shown earlier than in the acrosin case (a reduction of $51.5 \%$ was observed in week 12; Fig. 3).

\section{Retinol concentration}

Retinol concentration in ram blood plasma of the rams was always kept within the normal range $\left(20-50 \mu \mathrm{g} 100 \mathrm{ml}^{-1}\right)$. This happened in all three groups and throughout the experiment. It should be mentioned that during the last 4 weeks of the experiment, retinol concentration showed a short increase in the control group, exceeding $40 \mu \mathrm{g}$ $100 \mathrm{ml}^{-1}$. Although group B received vitamin A in a dose 4-fold higher than group A (controls), no statistically significant difference in retinol concentration was observed between these two groups. In group C, vitamin A was kept low during vitamin A deprivation, and returned to normal range by vitamin $A$ resupplementation (Fig. 4).

\section{Retinoic acid concentration}

In week 1 , retinoic acid was not detectable in the blood plasma of any ram group. From week 2, retinoic acid appeared in small concentrations in groups B and C, and was kept at these levels through the whole experiment. In weeks 2, 3, and 13 retinoic acid concentration in group B showed statistically significant differences compared with
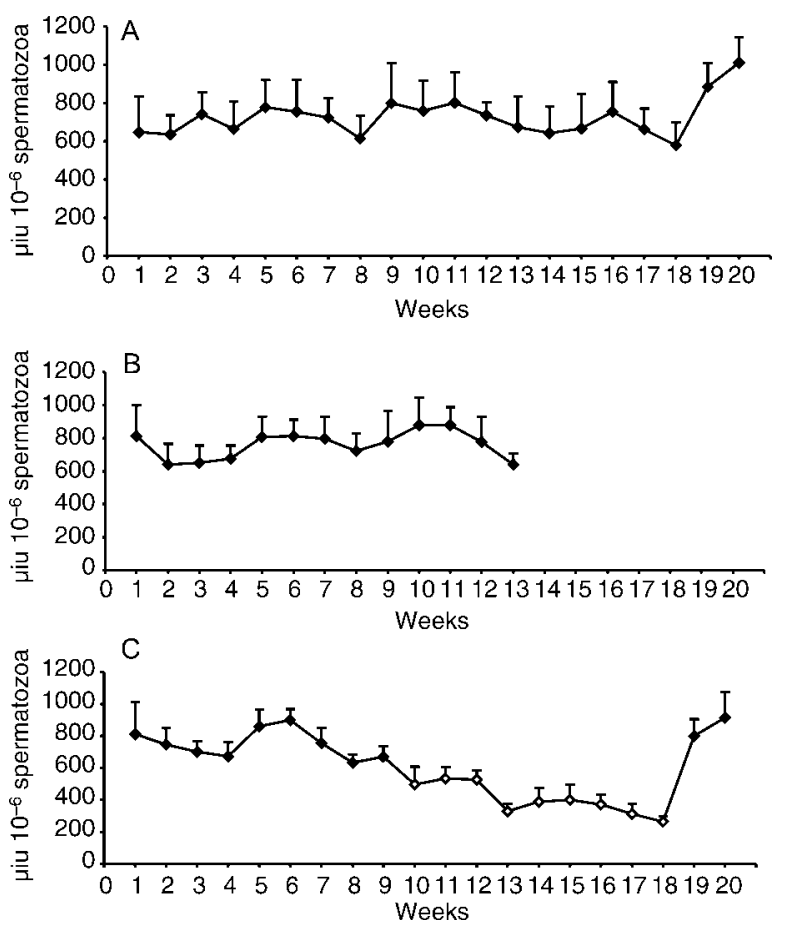

Figure 2 Mean ( \pm S.D.) values of acrosin activity of ram spermatozoa in $\mu$ iu $10^{-6}$ spermatozoa. $\diamond$ indicate statistical differences compared with controls $(P<0.05)$. Group A (controls), 12500 iu vitamin A/animal per day; group B, 50000 iu vitamin A/animal per day; group C, 0 iu vitamin A/animal per day until the 13th week, then 150000 iu vitamin A/animal per day until the end of the experiment. 


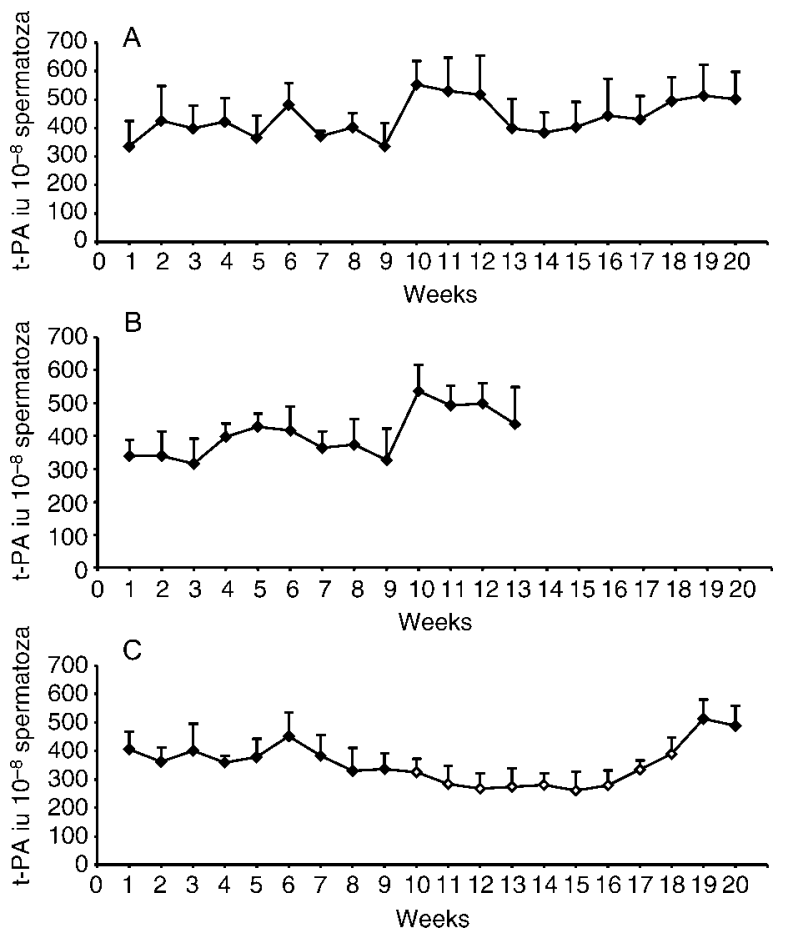

Figure 3 Mean ( \pm S.D.) values of PAA of ram spermatozoa in iu $10^{-8}$ spermatozoa. $\diamond$ indicate statistical differences compared with controls $(P<0.05)$. Groups are as in the Fig. 2 legend.

controls, but it should be noted that this observation was not consistent, while the $P$ value was very close to 0.05 . The comparison of the respective means of these specific weeks showed that this metabolite can be either higher or lower compared with controls. In group C, retinoic acid was not detectable until week 12. From week 13 it was steadily detectable and always in concentrations higher than those of the control group (Fig. 5).

\section{Retinyl ester concentration}

In week 1 , retinyl ester showed its lower concentration in group A, while it was not detectable in the other two groups. This metabolite increased through the following weeks in the control group. The same observation was made in group B. The only statistically significant differences between group $B$ and the control group were

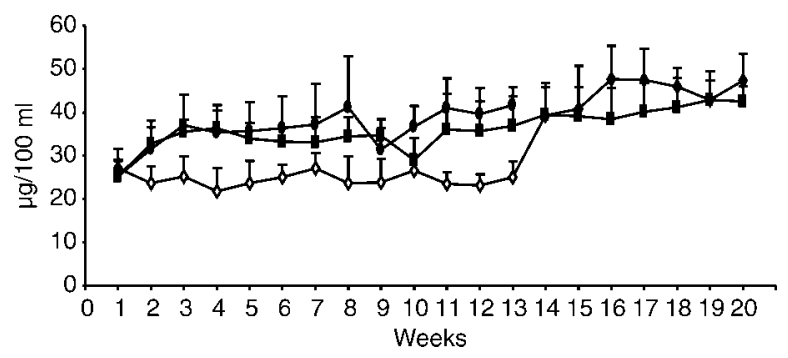

Figure 4 Mean ( \pm S.D.) values of retinol concentration in ram blood plasma (in $\mu \mathrm{g} 100 \mathrm{ml}^{-1}$ ). Open symbols indicate statistical differences compared with controls $(P<0.05)$. $\bullet$, group A (controls); $\bullet$, group $\mathrm{B} ; \bullet \bullet$, group $\mathrm{C}$. Groups are as in the Fig. 2 legend.

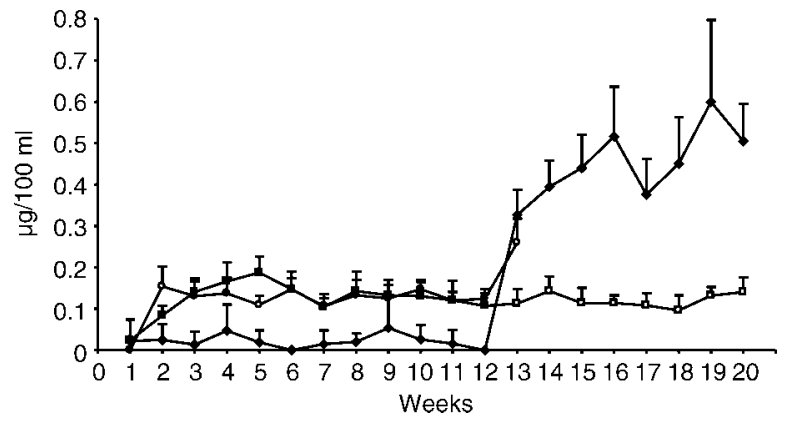

Figure 5 Mean ( \pm S.D.) values of retinoic acid concentration in ram blood plasma ( $\mu \mathrm{g} 100 \mathrm{ml}^{-1}$ ). Open symbols indicate statistical differences compared with controls $(P<0.05) . \bullet$, $\square$, group A (controls); $\bullet$, $\circ$, group $\mathrm{B} ; \bullet$, group $\mathrm{C}$. Groups are as in the Fig. 2 legend.

observed in weeks 2, 4, 7, and 12 but this was an inconsistent observation and the $P$ value was very close to 0.05 in these cases. In group $C$ retinyl ester was not detectable until week 13 . From week 14 it was steadily detectable, and after week 15 its concentration was significantly higher compared with controls (Fig. 6).

\section{Correlation}

There was a positive correlation between retinol concentration in blood plasma and the acrosin activity of group $\mathrm{C}(r=0.605, P<0.05)$, as well as between retinol concentration and PAA $(r=0.744, P<0.001)$. This correlation appeared with a 5 -week delay. It is noteworthy that the Pearson coeffficient was statistically significant even when it was estimated with a delay of 6 weeks for acrosin activity, and a delay of 2,3 , or 4 weeks for PAA, but its highest value was recorded when calculated after of 5-week delay. No significant correlation was found between retinoic acid concentration or retinyl ester concentration and any enzyme activity.

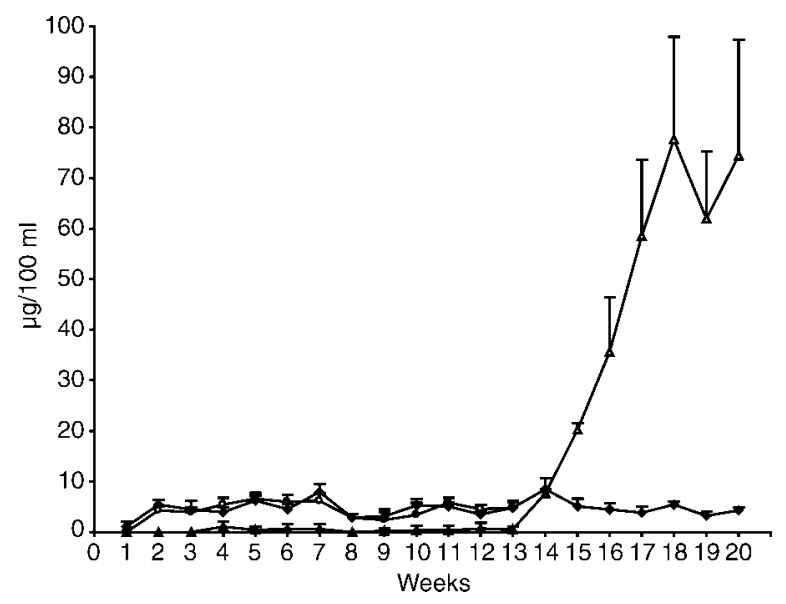

Figure 6 Mean ( \pm S.D.) values of retinyl ester concentration in ram blood plasma ( $\mu \mathrm{g} 100 \mathrm{ml}^{-1}$ ). Open symbols indicate statistical differences compared with controls $(P<0.05)$. $\bullet$, $\square$, group A (controls); $\bullet$, $\circ$, group $B ; \bullet$ group $C$. Groups are as in the Fig. 2 legend. 


\section{Discussion}

To our knowledge this is the first time that the effect of vitamin A on acrosomal enzyme activity has been investigated, taking into consideration not only retinol, but two more of its metabolites as well; retinoic acid and retinyl palmitate. These three retinoids were selected for the following reasons. First, retinol, bound to retinol-binding protein (RBP), is the main metabolite of vitamin A transported from the liver to target tissues. Second, retinyl palmitate is practically the only retinoid carried from the small intestine to the liver, in order to be either used or stored. Finally, retinoic acid is the intracellular active form of vitamin A, affecting the expression of various genes. For this purpose, retinoic acid is produced in the cell from retinol, while only a small quantity can diffuse from the blood into the cell (Blaner \& Olson 1994). Nevertheless, since the $75 \%$ of plasma retinoic acid is of tissue origin, this retinoid can also be an indicator of vitamin A status in the body (Wolf 2001).

Due to well-known homeostatic mechanisms, retinol concentration was maintained within the range of 20-50 $\mu \mathrm{g} \mathrm{ml}^{-1}$ during the whole experiment, as suggested by the reviewed literature. The slight increase in retinol concentration during the last few weeks of the experiment should be expected, since rams tend to have such an increase at the onset of the summer (Asadian et al. 1995). On the contrary, retinyl ester and retinoic acid concentrations showed significant changes during the experiment, being non-detectable during vitamin A deprivation, but reaching considerably higher levels after vitamin A resupplementation.

The Sertoli cell is the main site of retinol uptake by the testis. In these cells, vitamin A can be either stored or oxidized to retinoic acid and, after binding to specific nuclear receptors, affect the expression of various genes. Spermatocytes and spermatids also need vitamin A, which is delivered to them by the Sertoli cells essentially as retinol bound to RBP (Davis \& Ong 1992) or to cellular RBP (CRBP; Ong 1985), but also as retinyl ester (Kim \& Wang 1993) or retinoic acid (Livera et al. 2002). Since spermatocytes and spermatids are protected by the blood-testis barrier, the Sertoli cells are their basic suppliers of vitamin A (Kim \& Wang 1993). Nevertheless, during spermatogenesis, from spermatogonia A0 up to the stage of pachytene spermatocytes, germ cells can uptake retinol directly from the blood since they are not protected by the blood-testis barrier. Additionally, retinyl ester, when in high concentrations can diffuse into these germ cells from the blood (Blaner \& Olson 1994), and so can retinoic acid (Wolf 2001). It is noteworthy that vitamin A deprivation results in a decrease of RAR $\alpha$ in rat testis (Haq et al. 1991), as well as in a transportation of these nuclear receptors to the cytoplasm, where they are inactive (Livera et al. 2002).

In group B, the supplementation of vitamin A at a dose four times higher than the daily needs of the rams, and for
13 weeks, did not affect either enzyme activity. It seems that the supplementation of excessive vitamin A cannot affect the synthesis of these proteolytic enzymes, at least once the needs of the target cells have been covered. On the contrary, acrosin activity and PAA in group C decreased 108 days after vitamin A deprivation, and were kept low for 9 weeks. When retinol concentration in plasma is low, there is also a decrease of CRBP in testis (Rajan et al. 1990). This probably reduces the delivery of retinol to germ cells (Ong 1985). Since retinol is esterified only when bound to CRBP, germ cells receive less retinyl esters as well (Kim \& Wang 1993). Finally, CRBP is necessary for the oxidation of retinol to retinoic acid (Blaner \& Olson 1994). Since CRBP is not present in spermatocytes or spermatids (Huggenvik \& Griswold 1981), it seems that the only source of retinoic acid for these cells are the Sertoli cells (Cavazzini et al. 1996), which produce less retinoic acid in vitamin A deprivation. This results in a decrease of the retinoic acid delivered to the nucleus of the target cell, because delivery of retinoic acid occurs when this is bound to cellular retinoic acidbinding protein (CRABP), and this binding protein acts as a passive vehicle, which binds and releases its ligand according to concentration gradients (Noy 2000).

Retinoic acid, bound to CRABP, modulates nuclear gene expression by binding to specific receptors. These receptors bind as homo- or heterodimers to specific DNA sequences known as retinoic acid-response elements. To date, two such response elements have been identified, direct repeats DR-5 and DR-2, which are found in the promoters of several retinoic acid-responsive genes (Mangelsdorf 1994). At least in humans, DR-5 has been localized on the t-PA gene, and when retinoic acid binds to it the expression of the gene is enhanced (Bulens et al. 1995). On the contrary, no such response element was found on the mouse t-PA gene; this gene and its enhancer activator protein 1 are synergistically activated by CAMP and retinoic acid (Mira-y-Lopez et al. 1998).

During spermatogenesis, the biosynthesis of acrosin takes part in the meiotic phase or immediately after this (Kremling et al. 1991, Raab et al. 1994). A specific time point for the biosynthesis of PAs by the spermatogonia or the spermatids has not been determined. Nevertheless, pachytene spermatocytes and spermatids show an increased t-PA activity during stages IX-XII (Bardin et al. 1994). Therefore, the increased activity of t-PA, the type of $\mathrm{PA}$ to which the greatest percentage of PAA of ram spermatozoa is attributed (Smokovitis et al. 1987), coincides with the maximum concentration of CRABP and RAR $\alpha$ in germ cells as well.

Apart from direct regulation of gene expression, retinoic acid can also act indirectly, by regulating an intermediary, which in turn regulates the gene of interest, influencing mRNA stability, or activating nuclear receptor dimers other than the RAR-RXR complex (Balmer \& Blomhoff 2002). These include other receptors of the steroid receptor superfamily, such as the receptors of vitamin $D_{3}$ and 
thyroid hormone (Maden 2000). The two parts of the heterodimer have a synergistic effect on the activation of the target gene (Mangelsdorf 1994). Indeed, a response element on the human t-PA gene has been identified where the heterodimer of the RXR and the vitamin $D_{3}$ receptor binds and activates its transcription (Merchiers et al. 1999). In fact, it is known that vitamin $\mathrm{D}_{3}$ regulates PA synthesis by normal and malignant osteoblasts (Hamilton et al. 1985), the production of u-PA and PAI-1 by monocytes (Gyetko et al. 1988), and the synthesis of PA by epithelial and fibroblastic cells (Koli \& Keski-Oja 1996) or by rat heart microvascular cells (Puri et al. 2000).

Vitamin A deficiency is able to reduce plasma testosterone concentration in rats (Bartlett et al. 1989), and testosterone does affect acrosin activity (Theodosiadou 2000) and PAA (Rekkas et al. 1993). Nevertheless, in the Bartlett et al. (1989) study, the reduction of mean testosterone concentration was observed 112 days after the beginning of a vitamin A-deficient diet, while it is proved that 70-75 days after the supplementation of such a diet to rats spermatogenesis is arrested and the seminiferous epithelium degenerates irreversibly (Ismail et al. 1990). Since sperm counts, motility, and percentage of abnormal forms were not altered during our experiment, while our findings appeared a lot earlier in a species - the sheep - with a definitely greater capacity of storing vitamin A in the liver, we conclude that the possible effect of vitamin A deprivation on any enzyme activity via alterations of testosterone concentration should be excluded.

It is noteworthy that the effect on the activity of either enzyme was shown with a delay of 108 days for vitamin A deprivation and 42 days for vitamin A resupplementation. This is not surprising if we take into consideration that (1) sheep can cover their needs using vitamin A that they have already stored and (2) spermatogenesis in the ram lasts approximately 49 days, followed by the transportation of the spermatozoa in the epididymis for 16 days. This delay possibly supports the suggestion that the effect of vitamin A on acrosin and PAs of spermatozoa is exerted by regulating the biosynthesis of these enzymes during spermatogenesis, rather than the synthesis of PAs, PAls, or acrosin inhibitors that are taken up by the spermatozoa after they are released into the seminiferous tubule.

In conclusion, excessive vitamin $\mathrm{A}$ intake did not affect acrosin or PAA, but vitamin A deprivation reduced the activity of both enzymes in a reverse manner. Recent knowledge about vitamin A metabolism and action in the cell allows us to suggest that it may have influenced acrosin and PA synthesis during spermatogenesis by regulating gene expression, although other, indirect mechanisms of action should not be excluded. To date, the main result of vitamin A deficiency was known to be the arrest of spermatogenesis and testicular degeneration. A new role for vitamin $\mathrm{A}$ in the male reproductive system may be suggested, since it can influence factors related to male reproductive ability such as acrosin and PAs, before spermatogenesis is affected.

\section{Acknowledgements}

This study has been supported by a Greek State Scholarships Foundation grant. The authors declare that there is no conflict of interest that would prejudice the impartiality of this scientific work.

\section{References}

Asadian A, Mirhadi SA \& Mezes M 1995 Seasonal variation in the concentration of vitamins $A$ and $E$ in the blood plasma of fat-tailed sheep. Acta Veterinaria Hungarica 43 453-461.

Balmer JE \& Blomhoff R 2002 Gene expression regulation by retinoic acid. Journal of Lipid Research 43 1773-1808.

Bardin CW, Yan Cheng C, Mustow NA \& Gunsalus GL 1994 The Sertoli Cell. In The Physiology of Reproduction, 2nd edn, pp 1291-1333. Eds E Knobil \& JD Neill. New York: Raven Press.

Bartlett JMS, Weinbauer GF \& Nieschlag E 1989 Quantitative analysis of germ cell numbers and relation to intratesticular testosterone following vitamin A-induced synchronization of spermatogenesis in the rat. Journal of Endocrinology 123 403-412.

Blaner WS \& Olson JA 1994 Retinol and retinoic acid metabolism. In THE RETINOIDS: Biology, Chemistry, and Medicine, 2nd edn, pp 229-255. Eds MB Sporn, AB Roberts, DS Goodman. Goodman. New York: Raven Press.

Bulens F, Ibanez-Tallon I, Van Acker P, De Vriese A, Nelles L, Belayew A \& Collen D 1995 Retinoic acid induction of human tissue-type plasminogen activator gene expression via a direct repeat element (DR5) located at -7 kilobases. Journal of Biological Chemistry 270 7167-7175.

Cavazzini D, Galdieri M \& Ottonello S 1996 Retinoic acid synthesis in the somatic cells of rat seminiferous tubules. Biochimica et Biophysica Acta 1313 139-145.

Davis JT \& Ong DE 1992 The synthesis and secretion of retinol-binding protein by cultured rat Sertoli cells. Biology of Reproduction 47 528-533.

Declerck PJ, Boden G, Degreef H \& Collen D 1993 Influence of oral intake of retinoids on the human plasma fibrinolytic system. Fibrinolysis 7 347-351.

De Jonge CJ, Mack SR \& Zaneveld LJD 1989 Inhibition of the human sperm acrosome reaction by proteinase inhibitors. Gamete Research 23 387-397.

Deutsch DG \& Mertz ET 1970 Plasminogen purification from human plasma by affinity chromatography. Science 170 1095-1096.

Dufour JM \& Kim KH 1999 Cellular and subcellular localization of six retinoid receptors in rat testis during postnatal development: identification of potential heterodimeric receptors. Biology of Reproduction 61 1300-1308.

Gyetko MR, Webb AC \& Sitrin RG 1988 Modulation of urokinasetype plasminogen activator inhibitor-2 expression by U-937 mononuclear phagocytes. Effects of 1 alpha, 25-dihydroxyvitamin $D_{3}$ and phorbol ester. Journal of Immunology 141 2693-2698.

Hamilton JA, Lingelbach S, Partridge NC \& Martin TJ 1985 Regulation of plasminogen activator production by bone-resorbing hormones in normal and malignant osteoblasts. Endocrinology 116 2186-2191.

Haq RH, Pfahl M \& Chytil F 1991 Retinoic acid affects the expression of nuclear retinoic acid receptors in tissues of retinol-deficient rats. PNAS $888272-8276$.

Huang HFS, Li MT, Pogach LM \& Qian L 1994 mRNA of rat testicular RAR: developmental pattern, cellular distribution, and testosterone effect. Biology of Reproduction 51 541-550.

Huang X, Xia W, Xiong C, Xiao D, Shen J \& Zhou J 1997 Studies on the relationship between urokinase plasminogen activator (uPA) and human sperm motility. Journal of Tongji Medical University $\mathbf{1 7}$ $213-217$.

Huggenvik J \& Griswold MD 1981 Retinol binding protein in rat testicular cells. Journal of Reproduction and Fertility 61 403-408. 
Ismail N, Morales C \& Clermont Y 1990 Role of spermatogonia in the stage-synchronization of the seminiferous epithelium in vitamin-A-deficient rats. American Journal of Anatomy 188 57-63.

Jones R 1991 Interaction of zona pellucida glycoproteins, sulphated carbohydrates and synthetic polymers with proacrosin, the putative egg-binding protein from mammalian spermatozoa. Development 111 1155-1163.

Kennedy WP, Van der Ven HH, Straus JW, Bhattacharyya AK, Waller DP, Zaneveld LJD \& Polakoski KL 1983 Gossypol inhibition of acrosin and proacrosin, and oocyte penetration by human spermatozoa. Biology of Reproduction 29 999-1009.

Kennedy WP, Kaminski JM, Van der Ven HH, Jeyendran RS, Reid DS, Blackwell J, Bielfeld P \& Zaneveld LJD 1989 A simple, clinical assay to evaluate the acrosin activity of human spermatozoa. Journal of Andrology 10 221-231.

Kim KH \& Wang ZQ 1993 Action of vitamin A on the testis: Role of the Sertoli cell. In The Sertoli Cell, 1st edn, pp 517-535. Eds LD Russel \& MD Griswold. Clearwater, FL: Cache River Press.

Koli K \& Keski-Oja J 1996 Vitamin $D_{3}$ regulation of transforming growth factor-beta system in epithelial and fibroblastic cells-relationships to plasminogen activation. Journal of Investigative Dermatology: Symposium Proceedings 1 33-38.

Kooistra T, Opdenberg JP, Toet K, Hendriks HFJ, van den Hoogen RM \& Emeis JF 1991 Stimulation of tissue-type plasminogen activator synthesis by retinoids in cultured human endothelial cells and rat tissues in vivo. Thrombosis \& Haemostasis 65 565-572.

Kremling H, Keime S, Wilhelm K, Adham IM, Hameister H \& Engel W 1991 Mouse proacrosin gene: nucleotid sequence, diploid expression, and chromosomal localization. Genomics 11 828-834.

Lison D, Tas S, Gennart J-P, Psalti I, de Cooman S \& Lauwerys R 1993 Plasminogen activator activity and fertilizing ability of human spermatozoa. International Journal of Andrology $\mathbf{1 6}$ 201-206.

Liu K, Liu YX, Du Q, Zhou HM, Lin X, Hu ZY, Zhang GY \& Zhang GH 1996 Preliminary studies on the role of plasminogen activator in seminal plasma of human and rhesus monkey. Molecular Human Reproduction 2 99-104.

Livera G, Rouiller-Fabre V, Pairault C, Levacher C \& Habert R 2002 Regulation and perturbation of testicular functions by vitamin $\mathrm{A}$. Reproduction 124 173-180.

Maden M 2000 The role of retinoic acid in embryonic and postembryonic development. Proceedings of the Nutrition Society $\mathbf{5 9}$ $65-73$.

Mangelsdorf DJ 1994 Vitamin A receptors. Nutrition Reviews 52 S32-S44.

Mason KE 1933 Differences in testes injury and repair after vitamin A deficiency, vitamin E deficiency and inanition. American Journal of Anatomy 52 153-239.

Merchiers P, Bulens F, Stockmans I, De Vriese A, Convents R, Bouillon R, Collen D, Belayew A \& Carmeliet G 1999 1,25-Dihydroxyvitamin $D_{3}$ induction of the tissue-type plasminogen activator gene is mediated through its multihormone-responsive enhancer. FEBS Letters 460 289-296.

Mira-Y-Lopez R, Jaramillo S \& Jing Y 1998 Synergistic transcriptional activation of the mouse urokinase plasminogen activator (uPA) gene and of its enhancer activator protein 1 (AP1) site by cAMP and retinoic acid. Biochemical Journal 331 909-916.

Morales CR \& Griswold MD 1987 Retinol-induced stage synchronization in seminiferous tubules of the rat. Endocrinology 121 432-434.

Moulas AN, Zervos IA, Taitzoglou IA, Tsantarliotou MP \& Botsoglou NA 2003 Simultaneous determination of retinoic acid, retinol, and retinyl palmitate in ram plasma by liquid chromatography. Journal of Liquid Chromatography \& Related Technologies 26 559-572.

Noy N 2000 Retinoid-binding proteins: mediators of retinoid action. Biochemical Journal 348 481-495.

Ong DE 1985 Vitamin A-binding proteins. Nutrition Reviews 43 $225-232$.
Puri S, Bansal DD, Uskokovic MR \& MacGregor RR 2000 Induction of tissue plasminogen activator secretion from rat heart microvascular cells by $\mathrm{fM} 1,25(\mathrm{OH}) \mathrm{D}_{3}$. American Journal of Physiology Endocrinology \& Metabolism 278 E293-E301.

Raab LS, Hamilton DW \& Hancock LW 1994 Proacrosin and the differentiation of the spermatozoa. Journal of Andrology 15 244-249.

Rajan N, Sung WK \& Goodman DS 1990 Localization of cellular retinol-binding protein mRNA in rat testis and epididymis and its stage-dependent expression during the cycle of the seminiferous epithelium. Biology of Reproduction 43 835-842.

Rekkas C, Kokolis N \& Smokovitis A 1993 Breed and seasonal variation of plasminogen activator activity and plasminogen activator inhibition in spermatozoa and seminal plasma of the ram in correlation with testosterone in the blood. Andrologia 25 $101-109$

Saling PM 1981 Involvement of trypsin-like activity in binding of mouse spermatozoa to zonae pellucidae. PNAS $\mathbf{7 8}$ $6231-6235$.

Schill WB 1991 Some disturbances of acrosomal development and function in human spermatozoa. Human Reproduction 6 969-978.

Smith R, Jenkins A, Lourbakos A, Thompson P, Ramakrishnan V, Tomlinson J, Deshpande U, Johnson DA, Jones R, Mackie EJ \& Pike RN 2000 Evidence for the activation of PAR-2 by the sperm protease, acrosin: expression of the receptor on oocytes. FEBS Letters 484 285-290.

Smokovitis A, Kokolis N, Alexopoulos C, Alexaki E \& Eleftheriou E 1987 Plasimogen activator activity, plasminogen activator inhibition and plasmin inhibition in spermatozoa and seminal plasma of man and various animal species. Effect of plasmin on sperm motility. Fibrinolysis 1 253-257.

Smokovitis A, Kokolis N, Taitzoglou I \& Rekkas C 1992 Plasminogen activator: the identification of an additional proteinase at the outer acrosomal membrane of human and boar spermatozoa. International Journal of Fertility 37 308-314.

Sporn MB, Roberts AB \& Goodman DS 1994 In The Retinoids, 2nd edn. New York: Raven Press.

Srivastava PN, Munnel JF, Yang GH \& Foley GW 1974 Sequential release of acrosomal membranes and acrosomal enzymes of ram spermatozoa. Journal of Reproduction and Fertility $\mathbf{3 6}$ $363-372$.

Taitzoglou I, Kokolis N \& Smokovitis A 1996 Release of plasminogen activator and plasminogen activator inhibitor from spermatozoa of man, bull, ram and boar during acrosome reaction. Molecular Andrology 8 187-197.

Taitzoglou IA, Chapman DA \& Killian GJ 2003 Induction of the acrosome reaction in bull spermatozoa with plasmin. Andrologia 35 $112-116$.

Taitzoglou IA, Chapman DA, Zervos IA \& Killian GJ 2004 Effect of plasmin on movement characteristics of ejaculated bull spermatozoa. Theriogenology $62553-561$.

Tesarik J 1995 The role of proteases in the mammalian sperm acrosome reaction. In Human Sperm Acrosome Reaction, 1st edn, pp 133-149. Eds P Fénichel \& J Parinaud. Montrouge, France: Colloque INSERM/John Libbey Eurotext.

Tesařik J, Drahorád J \& Pěknicová J 1988 Subcellular immunochemical localization of acrosin in human spermatozoa during the acrosome reaction and zona pellucida penetration. Fertility \& Sterility $50133-141$.

Theodosiadou $\mathbf{E}$ The effect of breed, blood testosterone and season of the year on acrosin activity in spermatozoa of the ram. Doctoral thesis Aristotle University, Greece.

Thompson JGE \& Cummins JM 1985 The effects of washing and protein supplementation on the acrosome reaction of ram spermatozoa in vitro. Animal Reproduction Science 9 75-86.

van Bennecum AM, Emeis JJ, Kooistra T \& Hendriks HFJ 1993 Modulation of tissue-type plasminogen activator by retinoids in rat plasma and tissues. American Journal of Physiology 
Regulatory Integrative and Comparative Physiology 264 R931-R937.

van Pelt AMM \& de Rooij DG 1990 Synchronization of the seminiferous epithelium after vitamin $\mathrm{A}$ replacement in vitamin $\mathrm{A}-\mathrm{de}$ ficient mice. Biology of Reproduction 43 363-367.

van Pelt AMM \& de Rooij DG 1991 Retinoic acid is able to reinitiate spermatogenesis in vitamin A-deficient rats and high replicate doses support the full development of spermatogenic cells. Endocrinology 128 697-704.

Wolf G 2001 Retinoic acid homeostasis: Retinoic acid regulates liver retinol esterification as well as its own catabolic oxidation in liver. Nutrition Reviews 59 391-394.
Yanagimachi R 1994 Mammalian fertilization. In The Physiology of Reproduction, 2nd edn, pp 119-318. Eds E Knobil \& J Neill. New York: Raven Press.

Zaneveld LJD, Polakoski KL \& Williams WL 1973 A proteinase and proteinase inhibitor of mammalian sperm acrosomes. Biology of Reproduction 9 219-225.

Received 22 January 2004

First decision 11 May 2004

Revised manuscript received 3 November 2004

Accepted 3 March 2005 